\title{
Effect of DNA Gyrase Inhibitors and Urea on the Expression of cysB, the Regulatory Gene of the Cysteine Regulon
}

\author{
By ANNA BIELIŃSKA AND DANUTA HULANICKA* \\ Institute of Biochemistry and Biophysics, Polish Academy of Sciences, Rakowiecka 36, \\ 02-532 Warsaw, Poland
}

(Received 27 August 1985; revised 21 April 1986)

\begin{abstract}
$c y s B$, the regulatory gene of the cysteine regulon, is autoregulated. Inhibitors of both gyrase subunits, nalidixic acid and novobiocin, affect the expression of $c y s B$, as monitored by $\beta$ galactosidase activity in $c y s B$ : : lac fusion strains. In gyr $A$ mutants that are resistant to nalidixic acid, this drug does not affect $c y s B$ expression. The amount of mRNA transcribed from the $c y s B$ promoter isolated from cultures grown in the presence of gyrase inhibitors was significantly lower than that from the control culture without inhibitors. Urea also decreased $c y s B$ expression. These results suggest that DNA topology could play a role in cysB expression.
\end{abstract}

\section{INTRODUCTION}

The degree of supercoiling of DNA appears to be an important factor in control of gene expression (Smith, 1981). The DNA of bacteria, bacteriophages and plasmids is generally topologically constrained in a negatively supercoiled conformation. DNA supercoiling in vivo is a result of the balance between topoisomerase I and DNA gyrase, a type of topoisomerase II. DNA gyrase introduces negative superhelical turns into DNA and is composed of two subunits, $A$ and $B$, encoded by $g y r A$ and $g y r B$. Mutations that confer resistance to nalidixic acid or oxolinic acid map in gyr $A$, whereas mutations that result in coumermycin or novobiocin resistance map in $g y r B$.

Superhelical DNA is required for replication, plasmid maintenance and recombination of cellular DNA (Drlica, 1984). In vitro studies have shown that the superhelical density influences initiation of transcription (Botchan et al., 1973) and that changes in superhelicity affect different promoters differently (Botchan, 1976). In addition, in vivo and in vitro studies have shown that some genes are sensitive to gyrase inhibitors. It has been demonstrated that a reduction of supercoiling is strongly correlated with a change of gene expression (Shuman \& Schwartz, 1975; Smith et al., 1978; Kubo et al., 1979; DiNardo et al., 1982). Several studies have suggested that promoters under cAMP receptor protein regulation are particulary sensitive to gyrase inhibitors (Sanzey, 1979). However, work on gyrase inhibitors is complicated by these drugs having pleiotropic effects and causing severe growth inhibition. This makes urea particularly useful since it specifically affects gene expression without interfering with overall cellular metabolism (Sanzey \& Ullman, 1980).

cys $B$ is the regulatory gene of the cysteine regulon. Although considerable information is available concerning the regulation of the cysteine biosynthesis genes, little is known about the mechanism of cysB expression. Jagura-Burdzy \& Hulanicka (1981) have reported that $\operatorname{cys} B$ is autoregulated, but no other mechanisms of $c y s B$ regulation are known. It was thus of interest to study the relationship between DNA topology and $c y s B$ expression.

\section{METHODS}

Bacterial strains. All strains used were derivatives of Escherichia coli $\mathrm{K} 12$. Their characteristics are described in Table 1 . 
Table 1. E. coli strains and plasmid used

Strain

MC4100

EC1250

EC1173

EC1135

EC1230

EC1841

EC1842

E101

Plasmid

pLG400
Genotype*

araD139 $\Delta($ lac $) \mathrm{U} 169$ strA relA thi

araD139 $\Delta$ (lac)U169 strA relA thi trp

araD139 $\Delta($ lac $) \mathrm{U} 169$ strA relA thi trp cysB88::Mu d(Ap lac)

araD139 $\Delta($ lac $) \mathrm{U} 169$ strA relA thi trp cysE86:: Mu d(Apr lac)

araD139 $\Delta$ (lac-pro) thi trp cysB82::lac

EC1173 gyrAl

EC1173 gyrA2

dnaF $F_{\text {ts }}$ thr-1 thi-1 thy A6 deoC1 supE44 lacY tonA2 str

Contains a fragment of lacZ (Zabeau \& Stanley, 1982)
Reference or source

M. J. Casadaban, Univ. of Chicago, USA

Jagura-Burdzy \& Hulanicka (1981)

This work

Bielińska et al. (1984)

Jagura-Burdzy \& Hulanicka (1981)

This work

This work

Univ. of Gdańsk, Poland

Institute of Genetics,

Univ. of Warsaw, Poland

* The genetic nomenclature is from Bachmann et al. (1976).

Media and growth conditions. Sulphate-free medium (SF) was the minimal medium C, in which the sulphur source was $1 \mathrm{mM}$-L-cystine, $1 \mathrm{mM}$-L-djenkolate or $1 \mathrm{mM}$-glutathione. Glucose was added to $0.5 \%$. All solid media contained $1.5 \%(w / v)$ agar. Bacterial cultures were incubated with aeration at $37^{\circ} \mathrm{C}$. Antibiotics were added when cultures reached $\mathrm{OD}_{650}=0 \cdot 2-0 \cdot 3$.

Enzyme assays. $\beta$-Galactosidase was assayed in toluenized cells with $o$-nitrophenyl- $\beta$-D-galactopyranoside as substrate (Miller, 1972). O-Acetylserine sulphydrylase was determined as described previously (Kredich, 1971). Sulphite reductase was assayed by the method of deVito \& Dreyfuss (1964). Protein was determined by the biuret method using bovine serum albumin as a standard. DNA content in cells was determined by the Burton method with the modification of Giles \& Meyers (1965).

Isolation of gyr A mutants. Mutations were induced by adding $0.1 \mathrm{ml} 0.1 \% N$-ethyl- $N^{\prime}$-nitro- $N$-nitrosoguanidine to $5 \mathrm{ml}$ culture and shaking at $37^{\circ} \mathrm{C}$ for $30 \mathrm{~min} ; 0.1 \mathrm{ml}$ mutagenized culture was added to $10 \mathrm{ml} \mathrm{LB}$ and grown overnight. Spontaneous and $N$-ethyl- $N^{\prime}$-nitro- $N$-nitrosoguanidine-induced nalidixic acid resistant mutations of the fusion strains were isolated by plating about $10^{8}$ cells on the complete or minimal solid medium containing 20 $\mu \mathrm{g}$ nalidixic acid $\mathrm{ml}^{-1}$. The corresponding $g y r A$ mutations were identified by cotransduction with $d n a F$ by phage Plvir transduction.

Isolation of $R \bar{N} A$ and plasmid DNA. Total bacterial RNA was isolated by the phenol method (Ikemura \& Dahlberg, 1973). Plasmid DNA was isolated by the method of Holmes \& Quigley (1982).

Preparation of ${ }^{32}$ P-labelled plasmid DNA probe. Plasmid pLG400 DNA was labelled by nick translation (Mackey et al., 1977) with [ $\left.{ }^{32} \mathrm{P}\right]$ ATP or $\left[{ }^{32} \mathrm{P}\right] \mathrm{CTP}\left(410 \mathrm{Ci} \mathrm{mmol}^{-1}, 15 \mathrm{TBq} \mathrm{mmol}{ }^{-}\right)$(Amersham).

Electrophoresis, transfer and hybridization. Samples of total bacterial RNA were separated by electrophoresis through a $1.7 \%$ agarose gel with $2.2 \mathrm{M}$-formaldehyde. RNA was transferred from agarose to nitrocellulose paper by using $3 \mathrm{M}-\mathrm{NaCl} / 0 \cdot 3 \mathrm{M}$-trisodium citrate $(20 \times \mathrm{SSC})$ as described for DNA transfer by Southern (1975). Hybridization was done using the method of Wahl et al., (1979).

\section{RESULTS}

\section{Effect of gyrase inhibitors on the expression of cys $B$}

As the product of $\operatorname{cys} B$ has no enzyme activity, we used fusion strains where the lac operon was fused to the regulatory region of $c y s B$ to study its expression. In such strains, $\beta$-galactosidase synthesis is under the control of the regulatory elements of the cys $B$ system. The integration of the phage $\mathrm{Mu} \mathrm{d} l\left(\mathrm{Ap}^{\mathrm{r}} \mathrm{lac}\right)$ into cysB was checked by $\mathrm{Pl}$ transduction and transformation with plasmids containing $c y s B$.

To study the effect of gyrase inhibitors on cysB expression, overnight inocula of fusion strains were diluted and grown at $37^{\circ} \mathrm{C}$ with shaking. Different concentrations of inhibitors of the A and $B$ subunits of gyrase, nalidixic acid and novobiocin respectively, were added when the $\mathrm{OD}_{650}$ reached $0 \cdot 2-0 \cdot 3$. After two to three generations, samples were taken and $\beta$-galactosidase assayed (Miller, 1972). Both drugs inhibited expression of $c y s B$, as monitored by $\beta$-galactosidase activity, and the inhibition increased with increasing drug concentration (Table 2). Nalidixic acid also inhibited DNA replication. Even a low concentration $\left(5 \mu \mathrm{g} \mathrm{ml}^{-1}\right)$ stopped DNA sythesis, as measured by the Burton method (data not shown). (Nalidixic acid concentrations higher than $40 \mu \mathrm{g} \mathrm{ml}^{-1}$ could not be tested because growth was affected.)

To test whether the observed decrease of $\operatorname{cys} B$ expression was a result of inhibition of DNA 
Table 2. Effect of nalidixic acid and novobiocin on $\beta$-galactosidase activity in cys : lac fusion strains

$\beta$-Galactosidase activities of control cultures without inhibitors were taken as $100 \%$; these values were 730, 460 and 230 Miller units (Miller, 1972) for EC1173, EC1230 and EC1135 respectively. The results are means of three to five experiments; the deviations from these means were less than $7 \%$.

\begin{tabular}{|c|c|c|c|c|c|}
\hline Strain & Pertinent genotype & $\begin{array}{l}\text { Nalidixic acid } \\
\left(\mu \mathrm{g} \mathrm{ml}^{-1}\right)\end{array}$ & $\begin{array}{c}\beta \text {-Galactosidase } \\
\text { activity } \\
(\% \text { of control) }\end{array}$ & $\begin{array}{c}\text { Novobiocin } \\
\left(\mu \mathrm{g} \mathrm{ml}^{-1}\right)\end{array}$ & $\begin{array}{c}\beta \text {-Galactosidase } \\
\text { activity } \\
(\% \text { of control) }\end{array}$ \\
\hline \multirow[t]{4}{*}{ EC1173 } & cysB88::lac & 0 & 100 & 0 & 100 \\
\hline & & 10 & 17 & 20 & 64 \\
\hline & & 20 & 8 & 40 & 32 \\
\hline & & 40 & 7 & 80 & 25 \\
\hline \multirow[t]{2}{*}{ EC1230 } & cys $B 82:: l a c$ & 0 & 100 & 0 & 100 \\
\hline & & 20 & 93 & 80 & 95 \\
\hline \multirow[t]{2}{*}{ EC1135 } & cysE86::lac & 0 & 100 & 0 & 100 \\
\hline & & 20 & 93 & 80 & 100 \\
\hline
\end{tabular}

Table 3. Effect of nalidixic acid on $\beta$-galactosidase activity in cysB : : lac gyrA mutants

$\beta$-Galactosidase activities of control cultures without inhibitors were taken as $100 \%$; these values were 730,680 and 720 Miller units (Miller, 1972) for EC1173, EC1841 and EC1842 respectively. The results are means of three experiments; the deviations from these means were less than $10 \%$.

$\begin{array}{rccc}\text { Strain } & \text { Pertinent genotype } & \begin{array}{c}\text { Nalidixic acid } \\ \left(\mu \mathrm{g} \mathrm{ml}^{-1}\right)\end{array} & \begin{array}{c}\beta \text {-Galactosidase } \\ \text { activity } \\ (\% \text { of control })\end{array} \\ \text { EC1173 } & \text { cysB88::lac } \text { gyrA }^{+} \mathrm{Nal}^{\mathrm{s}} & 0 & 100 \\ & & 40 & 10 \\ \text { EC1841 } & \text { cysB88::lac gyrA1 Nal } & 0 & 100 \\ & & 40 & 95 \\ \text { EC1842 } & \text { cysB88::lac gyrA2 Nal } & 0 & 100 \\ & & 40 & 96\end{array}$

synthesis, two fusion strains were used as controls: EC1230 (cysB::lac) and EC1135 (cysE86: : lac). Previously it had been found that cysB expression was not autoregulated in strain EC1230 (Jagura-Burdzy \& Hulanicka, 1981). Probably some mutation had arisen in the regulatory region of $c y s B$ in the course of isolating the fusion. The second control strain, EC1135, carries the fusion in cys $E$, which is not affected by gyrase inhibitors (Ostrowski \& Hulanicka 1981). The lack of effect of both drugs on the expression of fused genes in control strains (Table 2 ) indicated the specific involvement of gyrase in expression of $c y s B$. Since the inhibitors of both subunits of gyrase affect cys $B$ expression, it is likely that the whole gyrase complex is involved in cys $B$ expression. Similar results were observed with all other $c y s B$ fusion strains studied.

To test if the effect of nalidixic acid concerns the gyrA product, the action of this drug on a resistant strain was studied. In fusion strains, nalidixic acid resistant mutations were isolated and their location in $g y r A$ was confirmed by $\mathrm{P} 1$ transduction. In all gyr $A$ nalidixic acid resistant strains, even at high concentrations $\left(40 \mu \mathrm{g} \mathrm{ml}^{-1}\right)$, the drug had no effect on the level of $\beta$ galactosidase (Table 3). This indicates that the effect of nalidixic acid is specific and that the gyr $A$ product is involved in the expression of $\operatorname{cys} B$.

\section{Effects of urea on cysB expression}

Gyrase inhibitors preferentially inhibit the expression of somes genes (Wei-jue et al. 1982). However, these drugs severly inhibit growth. At some concentrations urea inhibits the expression of catabolite sensitive genes without influencing bacterial growth (Sanzey \& Ullman, 1980). It was of interest to test if urea, which inhibits the expression of cysteine structural genes (Bielińska et al. 1984), affects the expression of cysB. Thus, the effect of urea on the $\beta$ galactosidase activity in the cysB : : lac fusion strains was examined (Table 4). Urea inhibited cys $B$ expression, and the inhibition increased with increasing urea concentration. Higher concentrations (above $0.6 \mathrm{M}$ ) were not examined because bacterial growth was affected. As in the previous experiments the control strains EC1230 and EC1135 were used. The inhibition of 
Table 4. Effect of urea on $\beta$-galactosidase activity in cys : : lac fusion strains

$\beta$-Galactosidase activities of control cultures without inhibitors were taken as $100 \%$; these values were 730,460 and 230 Miller units (Miller, 1972) for EC1173, EC1230 and EC1135 respectively. The results are means of three experiments; the deviations from these means were less than $10 \%$.

$\begin{array}{cccc}\text { Strain } & \text { Pertinent genotype } & \text { Urea (M) } & \begin{array}{c}\beta \text {-Galactosidase } \\ \text { activity } \\ \text { (\% of control) }\end{array} \\ \text { EC1173 } & \text { cysB88::lac } & 0 \cdot 0 & 100 \\ & & 0 \cdot 2 & 70 \\ & & 0 \cdot 4 & 30 \\ \text { EC1230 } & \text { cysB82::lac } & 0 \cdot 6 & 22 \\ & & 0 \cdot 0 & 100 \\ \text { EC1135 } & \text { cysE86::lac } & 0 \cdot 4 & 80 \\ & & 0 \cdot 0 & 100 \\ & & 0 \cdot 4 & 110\end{array}$

cys $B$ expression was specific since urea had little effect on the expression of $l a c Z$ in both control strains. To check if urea interfered with DNA replication, the DNA content of cells grown on different concentrations of this compound was assayed by the Burton method; even at $0.4 \mathrm{M}$ urea there was no interference with DNA synthesis (not shown). This result, and the lack of effect of urea on gene expression in the control strains, indicated that the decrease in $\beta$ galactosidase activity observed in the cysB::lac fusion strains was caused by specific interference with $c y s B$ expression by urea.

\section{Effect of gyrase inhibitors and urea on the transcription of cysB}

To show that gyrase inhibitors affect $c y s B$ expression at the transcriptional level, the amount of the transcript of lac mRNA directed from the $c y s B$ promoter was measured by hybridization using [ ${ }^{32}$ P]DNA of plasmid pLG400 as the probe. This plasmid contains a fragment of the lac operon without its own regulatory sequence (Zabeau \& Stanley, 1982). Total RNA was isolated from fusion strain EC1173 and also from EC1230 as the control, since cysB expression in the latter strain is not autoregulated and is insensitive to gyrase inhibitors and urea. Both strains were grown in the presence and absence of nalidixic acid $\left(20 \mu \mathrm{g} \mathrm{ml}^{-1}\right)$ and urea $(0.4 \mathrm{M})$. Isolated RNA was separated on an agarose-formaldehyde gel, transferred to nitrocellulose paper and hybridized with the probe.

Distinct bands of lac mRNA, visualized by hybridization and autoradiography, occurred in RNA isolated from cultures without inhibitors (Fig. 1, lanes 1 and 4), whereas the presence of nalidixic acid or urea significantly decreased the amount of mRNA directed from the cys $B$ promoter in strain EC1173 (Fig. 1, lanes 2 and 3). Similarly, as in the experiments in which $\beta$ galactosidase was assayed, these compounds had no effect on the expression of cys $B$ in fusion strain EC1230, although the bands (lanes 5 and 6) were slightly less intense than the control band (lane 4). Thus, a comparison of the RNA bands of EC1173 and EC1230 strains grown in the presence of inhibitors shows a significant difference in their intensity.

\section{DISCUSSION}

Recently there have been a number of indications that negative supercoiling of DNA stimulates the expression of many genes. Superhelical tension facilitates initiation of transcription and individual genes respond to changes in the degree of supercoiling. Yang $e$ t al. (1979) have studied the effect of gyrase inhibitors on the coupled transcription-translation system in a DNA-directed cell-free system. They found that the expression of different genes is reduced to different extents by inhibition of DNA gyrase activity. Smith et al. (1978) reported that transcription of the trp promoter carried on phage $\phi 80$ is insensitive to nalidixic acid. In contrast, this drug blocks transcription from the $P_{L}$ promoter of the same phage. Some other promoters, e.g. thr and early T7, are unaffected by gyrase inhibitors, while malP-mal $Q$, malKlamB, lac, gal, tna and T7 late promoters are sensitive to these drugs (Schuman \& Schwartz, 1975; DeWynagaert \& Hinkle, 1979; Drlica, 1984). The antibiotic coumermycin and temperature sensitive mutations affecting gyrase activity decrease RNA synthesis in vivo (Drlica, 1984). 


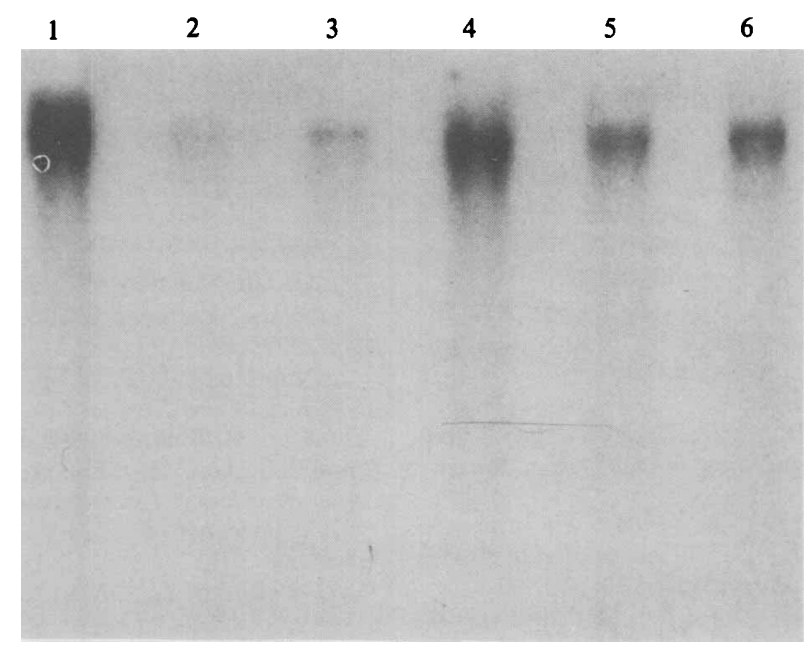

Fig. 1. Hybridization of RNA isolated from strains EC1173 (lanes 1, 2 and 3) and EC1230 (lanes 4, 5 and 6) with DNA of plasmid pLG400. The bacteria were grown in the presence of: no inhibitors (lanes 1 and 4); $20 \mu \mathrm{g}$ nalidixic acid $\mathrm{ml}^{-1}$ (lanes 2 and 5); $0.4 \mathrm{M}$-urea (lanes 3 and 6).

These treatments probably affect transcription by relaxing DNA superhelical tension. Significantly less is known about the mode of action of urea on DNA. Sanzey \& Ullman (1980) reported that urea interferes mainly with the initiation of transcription. Other authors (Levine $e t$ al., 1963) have shown that urea at a concentration similar to that used in our studies caused changes in the thermodenaturation profile of DNA. If the effect of urea in vivo is similar it is conceivable that urea could act by 'freezing' promoters and thus inhibiting the formation of an active complex. Promoters requiring additional activators for the binding of RNA polymerase might be more sensitive to urea.

In this paper we have shown that gyrase inhibitors and urea, the latter of which does not interfere with the overall cellular metabolism, decrease expression of $c y s B$, the regulatory gene of the cysteine regulon. Nalidixic acid and novobiocin also inhibit DNA replication. However, the decrease of cys $B$ expression is not caused by gene dosage effect, since it is not observed in the control strains EC1230 (cysB82 : :lac) and EC1135 (cysE86 : :lac). Previously it had been shown that $c y s E$ expression is not affected by gyrase inhibitors (Ostrowski \& Hulanicka, 1981). The fusion cysB82 : : lac is not autoregulated (Jagura-Burdzy \& Hulanicka, 1981), and fine genetic mapping by $P 1$ transduction showed that the fusion is within the regulatory region of $c y s B$ (Jagura-Burdzy, 1980). The fusion cysB82::lac was constructed by a two step technique (Casadaban, 1976); probably during isolation of this fusion an additional mutation arose in the promoter region which rendered cysB insensitive to autoregulation and independent on supercoiling for transcription. A similar case was reported for the lactose operon; in the lacUV5 mutant a change of two base pairs in the promoter region rendered this strain insensitive to catabolite repression and gyrase inhibitors (Wei-jue et al.,1982).

Urea, like gyrase inhibitors, decreased $c y s B$ expression and its effect was specific since it did not affect expression in control fusion strains (EC1135, EC1230) (Table 4 and Fig. 1). The decrease of cysB expression by inhibitors of DNA gyrase and by urea suggests that DNA topology might play a role in the regulation of expression of this gene.

\section{REFERENCES}

BACHMANN, B. J., LOW, K. B. \& TAYLOR, A. L. (1976). Recalibrated linkage map of Escherichia coli K-12. Bacteriological Reviews 40, 116-167.

Bielí́ska, A., Wiater, A. \& Hulanicka, D. (1984). The effect of urea on the cysteine regulon. Acta biochimica polonica 31, 77-82.
Botchan, P. (1976). An electron microscopy comparison of transcription on linear and superhelical DNA. Journal of Molecular Biology 105, 161-176.

Botchan, P., WaNG, J. C. \& Echols, H. (1973). Effect of circularity and supercoiling on the transcription from bacteriophage DNA. Proceedings of the Nation- 
al Academy of Sciences of the United States of America 70, 3077-3081.

CaSAdaban, M. J. (1976). Regulation of the regulatory gene for the arabinose pathway araC. Journal of Molecular Biology 104, 557-566.

DEWYNEGAERT, M. \& HiNKLE, D. S. (1979). Involvement of DNA gyrase in replication and transcription of bacteriophage T7 DNA. Journal of Virology 29, 529-535.

DiNardo, S., Voelkel, K. A. \& Sternglatz, R. (1982). Escherichia coli DNA topoisomerase I mutants have compensatory mutations in DNA gyrase genes. Cell 31, 43-51.

DrLICA, K. (1984). Biology of bacterial deoxyribonucleic acid topoisomerases. Microbiological Reviews 48, 273-289.

GILES. K. W. \& MYERS, A. (1965). An improved diphenylamine method for the estimation of deoxyribonucleic acid. Nature, London 206, 93.

Holmes, D. S. \& Quigley, M. (1982). Rapid boiling method for the preparation of bacterial plasmids. Analytical Biochemistry 114, 193-197.

IKemuRA, T. \& DAHLbERG, J. F. (1973). Small ribonucleic acid in Escherichia coli. Journal Biological Chemistry 248, 5033-5041.

JAGURA-BURDZY, G. (1980). Use of gene fusion to study expression of cys $B$, the regulatory gene of cysteine regulon. $\mathrm{PhD}$ thesis, Institute of Biochemistry and Biophysics, Polish Academy of Sciences, Warsaw, Poland.

Jagura-Burdzy, G. \& Hulanicka, D. (1981). Use of gene fusion to study the expression of the $c y s B$, the regulatory gene of the cysteine regulon. Journal of Bacteriology 147, 744-751.

KREDICH, N. M. (1971). Regulation of cysteine biosynthesis in Salmonella typhimurium. Journal of Biological Chemistry 246, 3474-3484.

Kubo. M., Kano, Y., Nakamura, H., Nagata, A. \& IMAMOTO, F. (1979). In vivo enhancement of general and specific transcription in Escherichia coli by DNA gyrase activity. Gene 7, 153-173.

LeVine, L., GoRdon, K. \& Jencke, W. P. (1963). The relationship of structure to the effectiveness of denaturing agents for deoxyribonucleic acid. Biochemistry 2, 168-175.

MaCkey, J. K., BrackmanN, K. H., Green, M. R. \& GreEN, M (1977). Preparation and characterisation of highly radioactive in vitro labelled adenovirus DNA and DNA restrictive fragments. Biochemistry 16, 4478-4483.
Miller, J. H. (1972). Experiments in Molecular Genetics. Cold Spring Harbor, NY: Cold Spring Harbor Laboratory.

Ostrowski, J. \& Hulanicka, D. (1981). Effect of gyrase inhibitors on the expression of the cysteine regulon. Molecular and General Genetics 181, 363366.

SANZEY, B. (1979). Modulation of gene expression by drugs affecting deoxribonucleic acid topoisomerase. Journal of Bacteriology 138, 40-47.

Sanzey, B. \& UllmanN, A. (1980). The effect of urea on catabolite sensitive operons in Escherichia coli. Molecular and General Genetics 178, 611-617.

Schuman, H. \& SchWaRTZ, M. (1975). The effect of nalidixic acid on the expression of some genes in Escherichia coli. Biochemical and Biophysical Research Communications 64, 204-209.

SOUTHERN, E. M. (1975). Detection of specific sequences among DNA fragments separated by electrophoresis. Journal of Molecular Biology 98, 503-517.

Smith, C., Kubo, M. \& Imamoto, F. (1978). Promoter specific inhibition of transcription by antibiotics which act on DNA gyrase. Nature, London 275, 420423.

SMITH, G. R. (1981). DNA supercoiling: another level for regulating gene expression. Cell 24, 599-600.

DEVito, P. C. \& Dreyfuss, J. (1964). Metabolic regulation of adenosinetriphosphate sulfurylase in yeast. Journal of Bacteriology 88, 1341-1348.

Wahl, G. M., SteRn, M. K. \& Stark, G. R. (1979). Efficient transfer of large DNA fragments from agarose gels into diazobenzyloxymethyl paper by using dextran sulphate. Proceedings of the National Academy of Sciences of the United States of America 76, 3683-3687.

Wei-Jue, CH., YANG, H. L., ZUbay, G. \& Gellert, M. (1982). The effects of supercoiling on the promoter function in procaryotes. In Promoter Structure and Function. pp. 242-251. Edited by R. L. Rodriguez \& M. T. Chamberlin, New York: Preager Publishers.

ZABEAU, M. \& Stanley, K. S. (1982). Enhanced expression of cro- $\beta$-galactosidase fusion protein under control of the $P_{R}$ promoter of bacteriophage $\lambda$. EMBO Journal 10, 1211-1224.

Yang, H. L., Heller, G., Gellert, M. \& Zubay, G. (1979). Differential sensitivity of gene expression in vitro to inhibitors of DNA gyrase. Prceedings of the National Academy of Sciences of the United States of America 76, 3304-3308. 